\title{
EVALUATION OF FEEDING RATES IN THE PRODUCTION OF LITOPENAEUS VANNAMEI SHRIMP USING ARTIFICIAL SUBSTRATES
}

\author{
AVALIAÇÃO DAS TAXAS DE ARRAÇOAMENTO NA PRODUÇÃO DO \\ CAMARÃO LITOPENAEUS VANNAMEI UTILIZANDO SUBSTRATOS \\ ARTIFICIAIS
}

\author{
César Rocha Nunes Antunes ${ }^{1^{*}}$ \\ Carlos Alberto da Silva Ledo ${ }^{2}$ \\ Clóvis Matheus Pereira ${ }^{3}$ \\ José dos Santos ${ }^{4}$ \\ ${ }^{1}$ University of the State of Bahia, Xique-Xique, BA, Brazil. \\ ${ }^{2}$ Embrapa Cassava and Fruticulture, Cruz das Almas, BA, Brazil. \\ 3Universidade Federal do Recôncavo da Bahia, Cruz das Almas, BA, Brazil. \\ ${ }^{4}$ Consultor of Bahia Protutiva CAR / World Bank, Ituberá, BA, Brazil. \\ ${ }^{*}$ Correspondig author - cesar@zootecnista.com.br
}

\begin{abstract}
The objective of this study was to evaluate the the influence of feeding rate and different artificial substrates on both the water quality and growth performance of Litopenaeus vannamei shrimp. The experimental design was randomized blocks with five treatments and four replicates, with a density of $30 \mathrm{shrimp} \mathrm{m}^{-2}$ and mean weight of $2.8 \mathrm{~g}$. The experiment lasted 49 days, and during this period, artificial substrates did not influence the water quality. The increase in the feeding rate influenced the dissolved oxygen of treatments. The final average weight, average final length, final biomass, productivity, and feed conversion rate showed significant differences $(p>0.05)$. The best food conversion factor was provided by the treatment with a feeding rate of $2 \%$. The treatment with a feeding rate of $4 \%$ of biomass showed the best growth performance, except for the feed conversion rate. Results showed that for the percentage of $25 \%$ of the area of artificial substrates, there is an optimum feeding rate of between $5.13 \%$ and $5.54 \%$ of shrimp biomass, resulting in maximum production.
\end{abstract}

Keywords: Biofilm, natural food, diets, shrimp farming.

\section{Resumo}

O objetivo deste trabalho foi avaliar a taxa de arraçoamento, sobre a influência dos substratos artificiais na qualidade da água e índices zootécnicos do camarão Litopenaeus vannamei. $\mathrm{O}$ delineamento experimental adotado foi em blocos casualizados com cinco tratamentos e quatro repetições, com densidade de 30 camarões $/ \mathrm{m}^{2}$, e peso médio de $2,8 \mathrm{~g}$, o experimento teve duração de 49 dias, durante este período os substratos artificiais não influenciaram na qualidade da água. $\mathrm{O}$ aumento da taxa de arraçoamento influenciou no oxigênio dissolvido dos tratamentos. O peso médio final, comprimento médio final, biomassa final, produtividade e fator de conversão alimentar apresentaram diferenças significativas $(p>0,05)$. O melhor fator de conversão alimentar foi 
proporcionado pelo tratamento com taxa de arraçoamento de $2 \%$. O tratamento com arraçoamento de 4\% da biomassa apresentou os melhores índices zootécnicos, com exceção do fator de conversão alimentar. Os resultados mostram que para o percentual de $25 \%$ de área de substratos artificiais existe um ótimo percentual de arraçoamento que está entre 5,13\% e 5,54\% da biomassa dos camarões resultando na maximização da produção.

Palavras - chave: Biofilme, alimento natural, dietas, carcinicultura.

Received on: April 17, 2018.

Accepted on: July 11, 2018.

\section{Introduction}

In the Brazilian shrimp farming industry, there is a predominance of semi-intensive and intensive cultivation of white shrimp (Litopenaeus vannamei). In 2016, the domestic production of this species reached 52,119 tons, presenting a reduction of $26.09 \%$ (70,521 tons) from that in $2015^{(1)}$.

Penaeid shrimp are omnivorous diggers that feed on a wide variety of benthic organisms and detritus. These shrimp have a continuous or frequent feeding activity ${ }^{(2)}$. The relative amount of each item consumed depends on its availability in the environment, and the growth stage and species of shrimp (3).

According to Viau et al. ${ }^{(4)}$, the biofilm adhered to substrates is formed by heterotrophic bacteria, filamentous cyanobacteria, ciliates, nematodes, and diatoms. Shrimp show higher growth and survival rates when cultured in the presence of biofilm, showing that the use of artificial substrates can reduce the negative effects caused by increased stocking density.

Any surface in contact with water naturally forms a community of microorganisms called a biofilm, its organic matrix also consists of microalgae, in particular diatoms, which are of great importance for the maintenance of water quality in shrimp culture ponds. Moreover, biofilms have components that are essential to the shrimp diet, such as vitamins and polyunsaturated fatty acids ${ }^{(5)}$.

Biofilms are beneficial to cultivated organisms due to the increased environmental productivity that they provide, as well as improved water quality and farming system health, which in turn provides increased survival rate, growth, and spatial distribution of animals. All benefits of biofilms may consequently decrease (improve) the feed conversion rate of diets ${ }^{(6,7-8)}$.

The variability in behavior and feeding habits of penaeid shrimp raised in shrimp culture ponds is still poorly understood. In semi-intensive cultures, diets are used to increase production beyond the levels supported by the natural productivity of the pond, which can reach up to $85 \%$ of the diet of shrimp ${ }^{(9)}$. However, it is important to define how feeding rates can influence the survival rate, growth, weight gain, total biomass, and productivity per hectare.

The aim of this study was to obtain information on the effect of using different feeding rates on both the water quality and growth performance of $L$. vannamei produced with artificial substrates. 


\section{Material and Methods}

The experiment was conducted over 49 days (November 9 to December 26, 2008) in a sandy-muddy bottom pond with an area of 1 ha and average depth of $1.5 \mathrm{~m}$, at the Bahia Pesca S.A. Oruabo Farm $\left(120^{\circ} 47^{\prime} \mathrm{S}, 380^{\circ} 46^{\prime} \mathrm{W}\right)$, in the municipality of Santo Amaro.

The initial procedures included total pond drying, soil correction with lime, pumping a supply of marine water from a catchment system installed in the estuary next to the Bay of All Saints, and filtration with a $1.0 \mathrm{~mm}$ mesh screen before filling the pond. The experimental design was randomized blocks, arranged in four blocks and five treatments for a total of 20 experimental plots. The treatments were as follows: treatment 1 (control), shrimp without artificial substrate and without feeding; treatments $2,3,4$, and 5 with artificial substrates and feeding rates of $0 \%, 2 \%, 4 \%$, and $6 \%$, respectively.

The experimental plots consisted of ponds of $4 \mathrm{~m}^{2}$ surrounded by polyethylene screens made with a mesh size of $1 \mathrm{~mm}(100 \%)$, black color, and height of $1.5 \mathrm{~m}$ fixed by four wooden stakes. Each pond was populated with a density of 30 shrimp $\mathrm{m}^{-2}$ for a total of 120 animals per experimental plot.

The plots were arranged parallel to the width of the pond, near the water outlet, where the pond was deeper, so that they had equal conditions of water circulation and depth, as well as being far enough away to avoid the influence of the side dikes.

The artificial substrates were made with the same screen as the plots, vertically fixed on stakes in the middle of the plot with a distance of $5 \mathrm{~cm}$ from the pond bottom, over a total of $25 \%\left(1 \mathrm{~m}^{2}\right)$ of the bottom area, according to the methodology of Domingos and Vinatea ${ }^{(10)}$. The artificial substrates were installed 21 days before starting the experiment for laying and colonization of the biofilm ${ }^{(11)}$.

The shrimp used in the experiment were produced at the shrimp farming laboratory located at Oruabo Farm. Post-larvae were transported to feed lots, where they remained for a period of 30 days and received powdered diets with $40 \%$ crude protein to reach an average weight of $2.8 \mathrm{~g}$, after which the juveniles were transferred to experimental plots.

The supply of commercial diets in treatments, with feeding rates of $2 \%, 4 \%$, and $6 \%$, was adjusted according to the shrimp biomass estimate obtained by biometrics performed during the cultivation period. The shrimp were fed with commercial diets with at least $30 \%$ crude protein supplied twice daily in trays (feeders), early in the morning and early in the afternoon.

Leftovers were controlled by collecting and freezing the non-consumed material in the feeders, ovendrying at $60{ }^{\circ} \mathrm{C}$ for $48 \mathrm{~h}$, according to the methodology of Silva and Queiroz ${ }^{(12)}$, and then weighing, to obtain the daily consumption rate and real feed conversion.

Biometry was performed weekly, collecting $10 \%$ of shrimp from each repetition of treatments. Shrimp were weighed (wet weight) using electronic precision scales $( \pm 0.01 \mathrm{~g})$ and measured with calipers. Soon after biometry, the shrimp were returned to the ponds.

During the experimental period, daily control of water quality of experimental plots was performed at $0600 \mathrm{~h}$ and $1400 \mathrm{~h}$. The following parameters were analyzed: salinity (Optical refractometer $\mathrm{Atago}^{\mathrm{TM}}$ ), with an accuracy of $1 \mathrm{ppt}$; dissolved oxygen (Microprocessor Oximeter AT 150, Alfakit), 
with an accuracy of $0-20 \mathrm{mg} \mathrm{L}^{-1} \pm 2 \%$ of reading; $\mathrm{pH}$ and temperature (pH meter AT 300, Alfakit), with an accuracy of $\pm 0.1 \%$, and transparency (Secchi disk). Ammonium analysis was carried out once a week (Card Kit Amônia Indotest). Water sample collections were performed in each of the experimental plots and also at a fixed random point within the limits of the pond, at least $20 \mathrm{~m}$ from the experimental plots, to characterize the water quality of the pond without the influence of the experimental unit.

To find the results of growth performance, the following formulas were used: survival rate [Surv\% $=($ final shrimp population $\times 100) /$ initial population], average weight gain $(\mathrm{AW}=$ total shrimp biomass/total number of shrimp); average length $(\mathrm{AL}=$ total shrimp length/total number of shrimp), total biomass $(\mathrm{TB}=$ average weight $\times$ final population); productivity $(\mathrm{Prod}=$ total biomass/area in ha); and feed conversion rate ( $\mathrm{FCR}=$ weight of feed consumed/total biomass) for each experimental plot and treatment.

The harvest was performed 49 days after the beginning of the experiment, by draining the ponds and collecting the shrimp with the aid of a net, for counting, weighing, and measuring. The shrimp were bagged, frozen, and identified according to the treatment and repetition.

Data related to physicochemical parameters, dry biofilm matter, final weight, survival rate, feed conversion rate, weight gain, total biomass, and productivity were submitted to analysis of variance (ANOVA). To compare the average of the control treatment with the other treatments, Dunnett's test at $5 \%$ probability was used. The means of treatments with artificial substrate were fitted into polynomial regression equations. Statistical analyses were performed using SISVAR statistical software ${ }^{(13)}$.

\section{Results and Discussion}

Throughout the experimental period, the water quality parameters showed variations considered normal for the cultivation of marine shrimp. The pond showed a Secchi disk transparency from0.30$0.47 \mathrm{~m}$, temperature of $26.5-30.8{ }^{\circ} \mathrm{C}$, salinity of $39.3 \%-39.6 \%$, ammonia level of $0.03-0.04 \mathrm{ppm}$, and $\mathrm{pH}$ of 7.88-8.9. There were no significant differences between the treatments for these parameters, and the given values are acceptable for shrimp cultivation ${ }^{(14,15)}$.

Dissolved oxygen was the only water quality parameter that showed a significant difference by Dunnett's $t$-test at $5 \%$ probability (Table 1 ).

Excess artificial feeding and metabolites originated by the shrimp cause water eutrophication as there is an increased nutrient load, and under this condition, the daily dissolved oxygen cycle varies widely, with low concentrations during the night and high concentrations during the afternoon. According to Boyd ${ }^{(16)}$, feeding rates above 40 to $50 \mathrm{~kg} \mathrm{ha}^{-1} \mathrm{day}^{-1}$ may cause unsuitable dissolved oxygen levels. In this study, the feeding rates ranged from 50-203.4 $\mathrm{kg} \mathrm{ha}^{-1} \mathrm{day}^{-1}$, influencing the dissolved oxygen concentrations. 
Table 1. Mean values and standard deviation of water physicochemical parameters in the different treatments

\begin{tabular}{|c|c|c|c|c|c|c|}
\hline Treatments & $\begin{array}{c}\text { Temperature } \\
\left({ }^{\circ} \mathrm{C}\right)\end{array}$ & $\begin{array}{c}\text { Salinity } \\
(\%)\end{array}$ & $\begin{array}{c}\text { Transparency } \\
\text { (m) }\end{array}$ & $\begin{array}{c}\text { Ammonium } \\
\text { (ppm) }\end{array}$ & $\mathrm{pH}$ & $\begin{array}{l}\text { Oxygen } \\
\left(\mathrm{mg} \mathrm{L}^{-1}\right)\end{array}$ \\
\hline 1 & $28.9 \pm 0.05$ & $39.4 \pm 0.98$ & $0.38 \pm 0.05$ & $0.03 \pm 0.003$ & 8.5 & $4.6 \pm 0.175$ \\
\hline 2 & $28.9 \pm 0.025$ & $39.3 \pm 0.15$ & $0.37 \pm 0.003$ & $0.03 \pm 0.0$ & 8.5 & $4.4 \pm 0.125$ \\
\hline 3 & $28.8 \pm 0.2$ & $39.4 \pm 0.2$ & $0.36 \pm 0.015$ & $0.03 \pm 0.003$ & 8.5 & $4.4 \pm 0.125$ \\
\hline 4 & $29.0 \pm 2.025$ & $39.4 \pm 0.125$ & $0.37 \pm 0.005$ & $0.04 \pm 0.005$ & 8.5 & $4.1 \pm 0.15$ \\
\hline 5 & $29.0 \pm 2.05$ & $39.6 \pm 0.15$ & $0.37 \pm 0.005$ & $0.04 \pm 0.005$ & 8.5 & $3.7 \pm 0.4$ \\
\hline
\end{tabular}

The Responsible Aquaculture program of the Global Aquaculture Alliance considers $3.0 \mathrm{mg} \mathrm{L}^{-1}$ as the minimum acceptable oxygen concentration in marine shrimp farming effluent, with a goal to establish a minimum quality of $4.0 \mathrm{mg} \mathrm{L}^{-1}{ }^{(18)}$. Therefore, the lowest average dissolved oxygen concentration in experimental treatments of this study $\left(3.7 \mathrm{mg} \mathrm{L}^{-1}\right.$ in treatment 5) was above the minimum value defined by the Global Aquaculture Alliance for the production of shrimp in captivity.

The highest amount of feed available in treatments coincided with the lowest dissolved oxygen concentrations, probably because there was a greater amount of residue from the feed.

The results of growth performance (Table 2), except for the survival rate, showed significant differences $(p<0.05)$ between treatments.

Table 2. Zootechnical indices of shrimp in the different treatments (standard deviation)

\begin{tabular}{ccccccc}
\hline Treatments & $\begin{array}{c}\text { Survival rate } \\
\mathbf{( \% )}\end{array}$ & $\begin{array}{c}\text { Average } \\
\text { weight gain } \\
(\mathbf{g})\end{array}$ & $\begin{array}{c}\text { Average } \\
\text { length }(\mathbf{c m})\end{array}$ & $\begin{array}{c}\text { Total } \\
\text { biomass } \\
(\mathbf{k g})\end{array}$ & $\begin{array}{c}\text { Productivity } \\
\left(\mathbf{k g ~ h a}^{-\mathbf{}}\right)\end{array}$ & FCR \\
\hline $\mathbf{1}$ & $94.1 \pm 1.5$ & $4.6 \pm 0.3$ & $8.0 \pm 0.3$ & $0.52 \pm 0.05$ & $1,297.3 \pm 105.5$ & - \\
$\mathbf{2}$ & $92.6 \pm 2.6$ & $4.7 \pm 0.5$ & $8.1 \pm 0.3$ & $0.52 \pm 0.06$ & $1,302.1 \pm 165.44$ & - \\
$\mathbf{3}$ & $95.1 \pm 2.5$ & $8.4 \pm 0.3$ & $9.9 \pm 0.15$ & $0.96 \pm 0.04$ & $2,400.4 \pm 97.9$ & $0.6 \pm 0.06$ \\
$\mathbf{4}$ & $98.2 \pm 1.6$ & $11.0 \pm 0.125$ & $10.8 \pm 0.13$ & $1.3 \pm 0.04$ & $3,244.6 \pm 87.8$ & $1.1 \pm 0.05$ \\
$\mathbf{5}$ & $93.6 \pm 3.7$ & $11.3 \pm 0.5$ & $11.0 \pm 0.25$ & $1.26 \pm 0.01$ & $3,145.3 \pm 19.0$ & $1.5 \pm 0.16$
\end{tabular}

(-) No feeding; (FCR) feed conversion rate.

The survival rate results showed no significant difference between treatments with and without artificial substrates, corroborating the study by Ballester et al. ${ }^{(19)}$, who carried out an experiment with or without use of artificial substrates and found no significant differences between the average survival rates of treatments. Dissimilarly, Schveitzer et al. ${ }^{(14)}$ found a significantly higher survival rate $(p<0.05)$ for treatments using artificial substrates compared to those without artificial substrates. To determine the best feeding rate, the means of the average final weight of treatments were adjusted to polynomial regression equations (Figure 1), according to Ferreira ${ }^{(13)}$. 


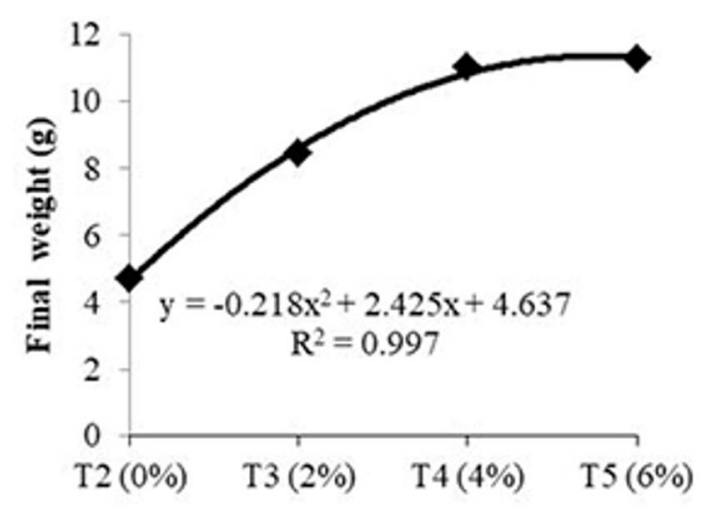

Feeding rate $(\%)$

Figure 1. Average final weight of shrimp fed with feeding rates of $0 \%, 2 \%, 4 \%$, and $6 \%$ in treatments with artificial substrates

The polynomial regression analysis shown in Figure 1 indicated that the ideal feeding rate with artificial substrates was $5.54 \%$ of the total shrimp biomass, favoring a higher performance in average weight.

The average weight gains in treatments 4 and 5 were above those found by Voltolina et al. ${ }^{(20)}$, who found an average weight gain of $1.08 \mathrm{~g} \mathrm{week}^{-1}$ for all treatments tested at $0,15,30$, and $45 \%$ of artificial substrates in the bottom area of ponds with a commercial diet.

The increased use of artificial substrates and use of appropriate amounts of diet can make the cultivation environment more balanced, which can maintain weight gain rates while reducing feed intake.

The polynomial regression analysis shown in Figure 2 indicated that a feeding rate of $5.37 \%$ provided the highest average length of shrimp.

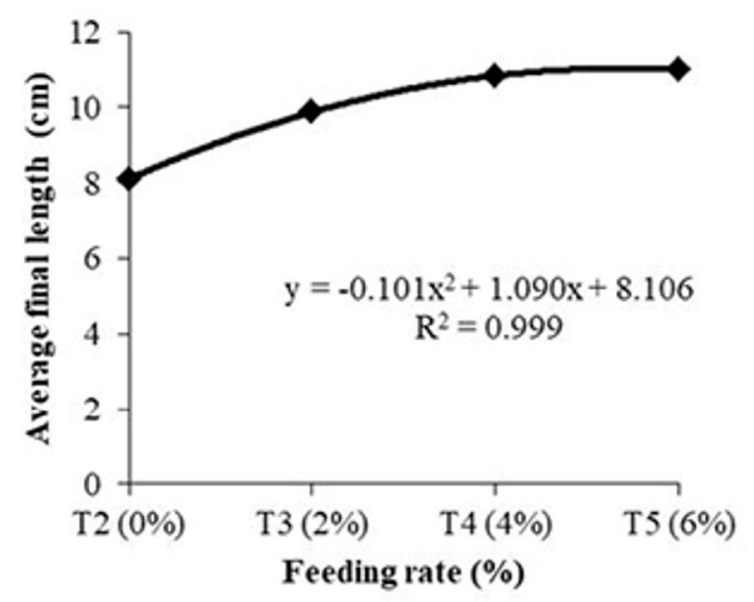

Figure 2. Average length of shrimp fed with feeding rates of $0 \%, 2 \%, 4 \%$, and $6 \%$ in treatments with artificial substrates

According to Viau et al. ${ }^{(21)}$, the large growth of shrimp post-larvae raised in ponds was a result of 
the nutritional contribution of the biofilm intake when shrimp were fed at a feeding rate of $50 \%$ of the total biomass.

To determine the best feeding rate, the average total biomass of treatments with artificial substrates were adjusted to polynomial regression equations (Figure 3), the results of which indicated that a feeding rate of $5.15 \%$ provided a greater total biomass; however, among experimental treatments, the feeding treatment with $4 \%$ of the total biomass showed the best results, suggesting that the treatment with the highest feeding rate $(6 \%)$, although very close to ideal, did not show the best performance.

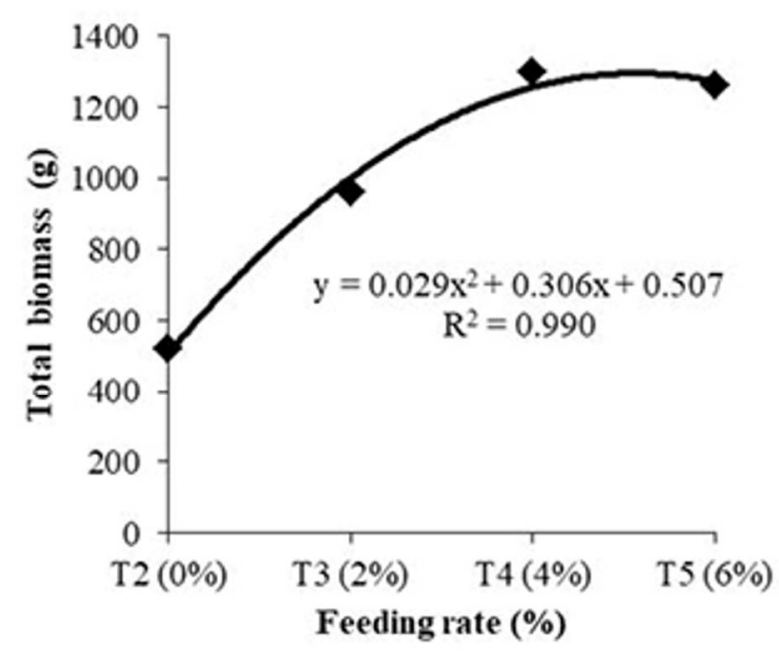

Figure 3. Total biomass of shrimp fed with feeding rates of $0 \%, 2 \%, 4 \%$, and $6 \%$ in treatments with artificial substrates

Zhang et al. ${ }^{(8)}$ reported that treatments with artificial substrates provide an increased survival rate, which reflects the significantly higher total biomass than that of the control treatment without substrates $(p<0.05)$, and also that feed intake was proportional to the biomass cultivated. This study showed the optimal feeding rate in relation to the final biomass, indicating that there are productivity limits to increases in the diet supply, after which excess feeding does not provide an increased biomass.

Only $15 \%-30 \%$ of feed consumed is converted into biomass for shrimp kept in captivity, feed not consumed contains phosphorus and nitrogen, identified as the main nutrient sources that degrade water quality in shrimp farming. The rest of the feed is lost to the sediment, effluent, and atmosphere (17).

In this context, the supply of feed should be rationalized due to both economic and environmental aspects. The biofilm participates as a diet component.

The statistical analysis of productivity (Figure 4) showed significant differences between treatments at $1 \%$ significance by the $F$-test. Treatment with a $4 \%$ feed rate showed the best productivity $(3,244.6$ $\pm 87.8 \mathrm{~kg} \mathrm{ha}^{-1}$ per cycle); however, according to the polynomial regression analysis of productivity means, the optimal feeding rate was $5.13 \%$.

The productivity found can be considered a good result. According to the criteria of Vinatea ${ }^{(22)}$, the results of this study in relation to productivity can be considered as a semi-intensive system $(700 \mathrm{~kg}$ $\mathrm{ha}^{-1}$ year $^{-1}$ up to $10 \mathrm{t} \mathrm{ha}^{-1}$ year $\left.^{-1}\right)$. The results of this study are higher than those $\left(1,799-2,061 \mathrm{~kg} \mathrm{ha}^{-1}\right.$ per cycle) reported by Márquez et al. ${ }^{(23)}$, which demonstrated the effectiveness of artificial substrates 
in relation to productivity without the use of this technology. The higher productivity gained in treatment 4 showed that this index can be maintained in commercial production standards, and feeding and biofilm made the system functional and productive.

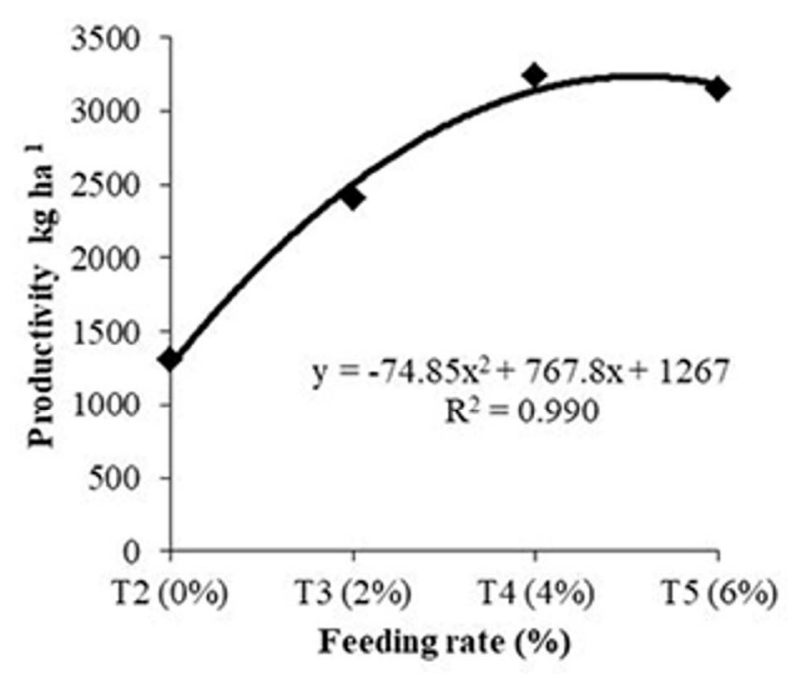

Figure 4. Productivity ( $\mathrm{kg} \mathrm{ha}^{-1}$ per cycle of 79 days) of shrimp fed with feeding rates of $0 \%, 2 \%, 4 \%$, and $6 \%$ in treatments with artificial substrates

The results of the feed conversion of the feed presented in Table 2 showed that as the amount of feed and feed consumption increases, the rate of growth of the shrimp rises to a maximum level; after this point, if meals are increased, the feed efficiency is low because the growth of the shrimp has already reached its maximum level.

It was found in this study that treatments 3 and 4 showed lower and better FCR values than those found by Zhang et al. ${ }^{(8)}$ and Schveitzer et al. ${ }^{(14)}$, which were 1.22 and 1.3-1.4, respectively; however, treatment 5 showed FCR values higher than those found by these authors (Figure 5). Moreover, the results of treatments 4 and 5 were those showing the best growth performance.

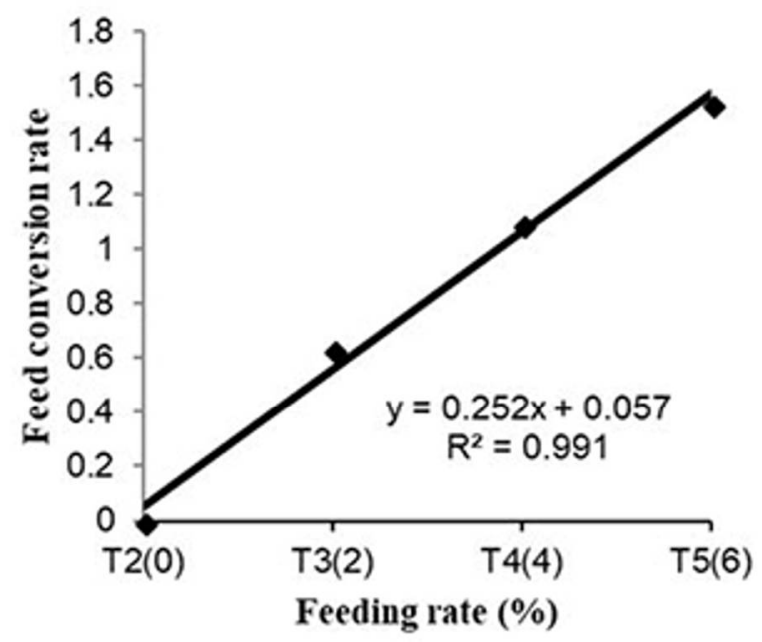

Figure 5. Feed Conversion Rate (FCR) of shrimp fed with feeding rates of $0 \%, 2 \%, 4 \%$, and $6 \%$ in treatments with artificial substrates

Despite the works of Huang et al. and Ferreira et al. ${ }^{(7,24)}$, which suggest that supplementation performed in the presence of the biofilm promoted by artificial substrates results in a better 
performance of the shrimp, in the present study, no improvement in the feed conversion ratio was observed with the increase in feeding rate. This also contradicts the results of Milstein et al. ${ }^{(25)}$, which documented a decrease of $30.0 \%$ in the feed conversion ratio due to the presence of the biofilm induced by artificial substrates.

In semi-intensive systems studied by Domingos and Vinatea ${ }^{(9)}$, the effect of using vertical artificial substrates showed different relationships between the substrate area and the pond bottom area $(0 \%$, $15 \%, 30 \%$, and $45 \%$ ) of the cultivation of $L$. vannamei shrimp, indicating that no differences between the treatments in relation to feed conversion and growth were found. This suggested that the benthic flora and fauna available in substrates were not able to meet the protein and/or energy demand of juvenile $L$. vanname $i$ with weights exceeding $4 \mathrm{~g}$ raised in the density of 30 shrimp $\mathrm{m}^{-2}$.

Thus, this study showed that artificial substrates can be an important tool in the production process of shrimp in semi-intensive systems, and that the nutritional quality of the biofilm can be an excellent supplement to the diet of L. vannamei.

\section{Conclusions}

Artificial substrates did not influence the water quality for shrimp farming.

The feeding rate showed ideal values ranging from $5.13 \%-5.54 \%$, resulting in maximum productivity.

Further research should be carried out in order to increase the percentage of $25 \%$ of the area of artificial substrate in cultured marine shrimp.

\section{Acknowledgments}

To Bahia Pesca for providing the structure, biological material, and flexibility in work schedules, and to the Federal University of Reconcavo da Bahia for the opportunity to participate as a graduate student in the Masters Degree Program in Animal Science.

\section{References}

1. BRASIL - Instituto Brasileiro de Geografia e Estatística. Produção da Pecuária Municipal - 2016, Brasília, 2017. Disponível em: <_https://www.ibge.gov.br/media/com.../ ea77821e06cad1457f9b35c1abe2137f.pdf. Acesso em: 27 de junho de 2018.

2. Nevejan N, De Schryver P, Wille M. . Bacteria as food in aquaculture: do they make a difference? Reviews in Aquaculture. 2016; 10:180-212.

3. Lima JF, Garcia J, Silva T C. da. Natural diet and feeding habits of a freshwater prawn (Macrobrachium carcinus: Crustacea, Decapoda) in the estuary of the Amazon River. Acta Amazonica. 2014; 44(2) : 235 - 244.

4. Viau V E, Marciano A, Iriel A, Greco L S L. Assessment of a biofilm-based culture system within zero water exchange on water quality and on survival and growth of the freshwater shrimp Neocaridina heteropoda 
heteropoda. Aquaculture Research. 2016; 47: 2528-2542.

5. Audelo-Naranjo J M. Intensive culture of Litopenaeus vannamei without water exchange and with an artificial substrate. Hidrobiológica. 2012; 22: 1-7.

6. Lara G, Honda M, Poersch L, Wasielesky Jr W. The use of biofilm and different feeding rates in biofloc culture system: the effects in shrimp growth Parameters. Aquaculture International. 2017; 25:1959-1970.

7. Huang Z, Wan R, Song X, Hallerman E. Assessment of AquaMats for removing ammonia in intensive comercial Pacific white shrimp Litopenaeus vannamei aquaculture systems. Aquaculture International. 2013; 21(6):1333-1342.

8. Zhang J, Chen L, Dong H, Duan Y, Li Zhuojia, Wen G, Chen J, Feng Z, Xu W, Xie J. Artificial substrates in zero-water-exchange culture system regulate the rearing performance of Pacific white shrimp Litopenaeus vannamei (Boone, 1931) under the winter indoor condition. Aquaculture Research. 2016; 47(1):91-100.

9. Audelo-Naranjo JM. Water quality, production parameters and nutritional. Aquaculture Research. 2011; 42: 1371-1377.

10. Domingos JAS, Vinatea L. Efeito do Uso de diferentes quantidades de substratos artificiais na engorda do camarão marinho Litopenaeus vannamei (Boone, 1931), em um sistema de cultivo semi-intensivo. Boletim do Instituto de Pesca. 2008;34:141-150.

11. Abarzua S, Jakubowshi A. Biotechnological Investigation for the Prevention of Biofouling. I. Biological and Biochemical Principles for the Prevention of Biofouling. Marine Ecology Progress Series. 1995;123:301312.

12. Silva DJ, Queiroz AC. Análise de alimentos (Métodos químicos e biológicos). $3^{\mathrm{a}}$ Edição, Viçosa, MG. Universidade Federal de Viçosa, 2004. 235p.

13. Ferreira, DF. Daniel Furtado. Sisvar: a computer statistical analysis system. Ciência e Agrotecnologia.2011; 35(6): 1039-1042.

14. Schveitzer R, Arantes R, Baloi MF, Costódio PFS, Arana LV, Seiffert WQ, Andreatta ER.Use of artificial substrates in the culture of Litopenaeus vannamei (biofloc system) at different stocking densities: effects on microbial activity, water quality and production rates. Aquacultural Engineering. 2013; 54:93-103.

15. Gaona CAP, Almeida MS, Viau V, Poersch LH, Wasielesky WJ. Effect of different total suspended solids levels on a Litopenaeus vannamei (Boone, 1931) BFT culture system during biofloc formation. Aquaculture Research. 2015; 48:1070-1079.

16. Boyd CE. Manejo da qualidade de água na aquicultura e no cultivo do camarão marinho. 1. ed. Recife: ABCC, 2003. 157p.

17. Boyd CE. Guidelines for aquaculture effluent management at the farm level. Aquaculture. $2003 ; .226: .101-$ 112.

18. Boyd CE. Parâmetros da qualidade de água: oxigênio dissolvido. Revista da Associação Brasileira de Criadores de Camarão. : 2002 .4: (1):.66-69..

19. Ballester ELC, Wasielesky WJ, Cavalli RO, Santos MHS, Abreu PC. Influência do Biofilme no Crescimento do Camarão-Rosa Farfantepenaeus paulensis em Sistemas de Berçários. Atlântica.. 2003;25(2):117-122.

20. Voltolina D, Watson-Toscano JE, Romero-Beltrán E, Audelo-Naranjo J, M. Nitrogen Recycling in Closed Cultures of Litopenaeus vannamei (Boone 1931) with Different Artificial Substrates. The Israeli Journal of Aquaculture. 2013;.65:.907-913. 
21. Viau VE, Souza DM, Rodríguez EM, Wasielesky WJ, Abreu PC, Ballester ELC.Biofilm feeding by postlarvae of the pink shrimp Farfantepenaeus brasiliensis (Decapoda, Penaidae). Aquaculture Research. 2013; 44:783-794.

22. Vinatea LA. Princípios químicos de qualidade da água em aquicultura: uma revisão para peixes e camarões. Florianópolis-SC: Ed. da UFSC, 2004. 231p.

23. Márquez JEQ, Andreatta ER,Vinatea L, Olivera A, Brito LO. Effect of stocking density on zootechnical parameters of shrimp Litopenaeus schmitti culture. Boletim do. Insituto da. Pesca.2012; 38(2): 145 - 153.

24. Ferreira L MH,.; Lara G, Wasielesky WJ, Abreu PC. Biofilm versus biofloc: Are artificial substrates for biofilm production necessary in the BFT system? Aquacult International. 2016; 24:921-930.

25. Milstein A, Joseph D, Peretz Y, Harpatz S. Evaluation of organic Tilapiaculture inperiphyton-basedponds. Israeli Journal of Aquaculture Bamidgeh. 2005; 57,143-155. 